\title{
PENGARUH ISLAMIC MARKETING TERHADAP KEPUASAN DAN LOYALITAS NASABAH PADA BANK MUAMALAT CABANG MALANG
}

\author{
Langgeng Setyono \\ Universitas Brawijaya \\ langsetyono@ub.ac.id \\ Malang, Indonesia
}

\begin{abstract}
In Indonesia, Bank Muamalat is the first bank in existence. With such a large Muslim population, on the other hand, Islamic banks do not hold market share in the national banking industry. Islamic banks lag behind other conventional banks. Therefore, a strategy is needed to increase that market share. Islamic marketing is a strategy that can be used to increase customer satisfaction and loyalty at Bank Muamalat Indonesia.

This research is an explanatory research with a quantitative approach. The sampling technique used in this study was purposive sampling. Respondents in this study were 120 people. The Machine and Campbell formula is used to determine the number of respondents. The objectives of this study are (1) to determine the effect of Islamic marketing on customer satisfaction; (2) to determine the effect of Islamic marketing on customer loyalty; (3) To determine the effect of customer satisfaction on customer loyalty.

The results of this study are (1) Islamic marketing has a significant effect on customer satisfaction; (2) Islamic marketing has a significant effect on customer loyalty; and (3) Customer satisfaction has a significant effect on customer loyalty. So that Bank Muamalat in increasing customer satisfaction and loyalty needs to improve the existing indicators in Islamic Marketing.
\end{abstract}

Keywords: Customer Satisfaction; Customer Loyalty; Islamic Marketing

\begin{abstract}
Abstrak
Di Indonesia, Bank Muamalat merupakan bank pertama yang ada. Dengan besarnya penduduk muslim tersebut justru sebaliknya bank Syariah bukanlah pemegang pangsa pasar pada industri perbankan nasional. Bank Syariah tertinggal oleh bank konvensional lainnya. Maka dari itu diperlukan strategi untuk meningkatkan pangsa pasar tersebut. Islamic marketing merupakan strategi yang bisa digunakan untuk meningkatkan kepuasan dan loyalitas nasabah yang ada pada Bank Muamalat Indonesia.

Penelitian ini merupakan penelitian ekplanatory dengan pendekatan kuantitatif. Teknik sampling yang digunakan dalam penelitian ini adalah purposive sampling. Responden dalam penelitian ini adalah 120 orang. Rumus Machin and Campbell digunakan untuk menentukan jumlah responden. Tujuan dari penelitian ini adalah (1) untuk mengetahui pengaruh Islamic marketing terhadap kepuasan nasabah; (2) untuk mengetahui pengaruh Islamic marketing terhadap loyalitas nasabah; (3) Untuk mengetahui pengaruh kepuasan nasabah terhadap loyalitas nasabah.

Hasil dari penelitian ini adalah (1) Islamic marketing secara signifikan berpengaruh terhadap kepuasan Nasabah; (2) Islamic marketing berpengaruh signifikan terhadap loyalitas nasabah; serta (3) Kepuasan nasabah berpengaruh signifikan terhadap loyalitas nasabah. Sehingga Bank Muamalat di dalam meningkatkan kepuasan dan loyalitas nasabahnya perlu meningkatkan Indikator-indikator yang ada pada Islamic Marketing tersebut.
\end{abstract}

Kata Kunci: Islamic Marketing; Kepuasan Nasabah; Loyalitas Nasabah

Open Access at:http://ojs.uho.ac.id/index.php/PUBLICUHO/index

Journal Publicuho is licensed under a Creative Commons Attribution 4.0 International License. 


\section{PENDAHULUAN}

Indonesia adalah salah satu negara yang memiliki populasi penduduk yang beragama Islam yang paling besar di dunia. Berdasarkan data yang disajikan oleh Badan Pusat Statistik terdapat jumlah penduduk 207.176.162 jiwa atau 87,18\% penduduk yang menganut agama Islam. Dalam konteks pemasaran, konsumen muslim yang besar mempunyai posisi strategis dan potensial untuk dikembangkan, oleh karena itu penduduk muslim merupakan peluang bagi dunia bisnis.

Konsumen muslim mempunyai karakter yang unik karena terikat dengan aturan agama. Agama yang dianut oleh konsumen muslim adalah keyakinan yang dianut yang memberikan seperangkat petunjuk, tata cara hidup dan berisi amalan dalam kehidupan sehari-hari yang syumul (sempurna). Prinsip hidup ini harus diperhatikan oleh pemasar yang tertarik dengan pasar konsumen Muslim. Dengan demikian pemasar membutuhkan strategi pemasaran yang berbeda yang sesuai dengan prinsip-prinsip Islam. Salah satu strategi yang dapat digunakan adalah Islamic Marketing.

Bank Muamalat Indonesia merupakan bank syariah yang menerapkan konsep Islamic Marketing Bank Muamalat memiliki pertumbuhan kinerja keuangan yang tinggi. Berdasarkan laporan tahunan Bank Muamalat tahun 2018 menunjukkan Compound Annual Growth Rate (CAGR) aset dari tahun 2009 hingga 2013 sebesar 35,92\%. Laju pertumbuhan pembiayaan Bank Muamalat juga tergolong pertumbuhan tinggi. CAGR of financing (gross) lima tahun terakhir menunjukkan 32,82\% dan jumlahnya terus meningkat setiap tahun. Dalam setengah dekade pertumbuhan pendapatan sebelum pajak lebih dari 70\%. CAGR pendapatan sebelum pajak dari tahun 2009 ke 2018 adalah 78,24\%. (Bank Muamalat, 2018)

Berdasarkan kinerja keuangan dapat disimpulkan bahwa Bank Muamalat menunjukkan kekuatannya sebagai salah satu bank nasional terkemuka di Indonesia, namun perkembangan kinerja keuangan tersebut tidak diikuti dengan pertumbuhan pangsa pasar. Indonesia hanya 4,9\% jika dibandingkan dengan bank konvensional yang 95,1\%. Pangsa pasar bank syariah tergolong kecil. Bank Muamalat memiliki 29,92\% dari total pangsa pasar bank syariah (Bank Muamalat, 2018).

Diperlukan strategi untuk meningkatkan pangsa pasar Bank Muamalat dengan mengukur kemampuan bank dalam menyediakan produk dan layanan kepada nasabah. Indikator yang dapat digunakan untuk mengukur kemampuan pelayanan bank adalah kepuasan nasabah dan loyalitas nasabah. Kepuasan pelanggan adalah sejauh mana konsumen memandang individu, perusahaan atau organisasi telah efektif dalam menyediakan produk atau layanan yang memenuhi kebutuhan konsumen. (Cengiz, 2010). Sedangkan loyalitas pelanggan dikaitkan dengan perilaku pembelian berulang dan dalam konteks loyalitas merek mencerminkan komitmen psikologis terhadap merek tertentu (Tjiptono, 2008). 


\section{Journal Publicuho}

ISSN2621-1351 (online), ISSN 2685-0729 (print)

Volume 4 Number 2 (May-July), (2021)pp. 239-247

Accredited SINTA SK.NOMOR 28/E/KPT/2019

Open Access at:http://ojs.uho.ac.id/index.php/PUBLICUHO/index DOI: 10.35817/jpu.v4i2.17704

Pada tahun 2014, Care Center for Customer Satisfaction and Loyalty (Care CCSL) mengadakan Excellent Service Experience Award (ESEA). Ini adalah penelitian layanan yang sangat baik untuk perusahaan bisnis di Indonesia termasuk industri perbankan. Pengukuran pelayanan keunggulan menggunakan Excellence Service Experience Index (ESEIndex). Pada 2014, riset Indeks ESEl menunjukkan Bank Muamalat berada di urutan keempat (Marketing.co.id). Posisi keempat Bank Muamalat tergolong rendah dibandingkan bank lain yang tergolong baru. Berdasarkan pengukuran indeks citra perusahaan Bank Muamalat menempati posisi kedua setelah Bank Syariah Mandiri. Bank Muamalat memiliki kategori sangat baik dalam indeks citra perusahaan, namun jumlahnya menurun (imacaaward.com, 2016)

Berdasarkan penjelasan latar belakang tersebut dapat diketahui bahwa Bank Muamalat merupakan bank syariah dengan pertumbuhan kinerja keuangan yang tinggi tetapi tidak mengikuti pertumbuhan pangsa pasar dibandingkan dengan bank konvensional. Berdasarkan hasil riset excellence service yang mempengaruhi kepuasan nasabah dan loyalitas nasabah, Bank Muamalat hanya menempati posisi keempat.

Alternatif strategi yaitu dengan menerapkan Islamic Marketing untuk meningkatkan kepuasan dan loyalitas nasabah sehingga diharapkan pangsa pasar Bank Muamalat semakin meningkat. Dengan demikian, penelitian ini akan menguji faktor-faktor yang mempengaruhi kepuasan pelanggan dan loyalitas pelanggan, seperti Islamic Marketing.

\section{METODOLOGI}

Berdasarkan tujuan penelitian, penelitian ini adalah penelitian eksplanatori dan menggunakan pendekatan kuantitatif. Pengukuran dalam penelitian ini menggunakan skala likert. Lokasi penelitian adalah Kantor Cabang Bank Muamalat Malang. Populasi penelitian adalah jumlah nasabah Bank Muamalat Cabang Malang yang menggunakan produk tabungan.

Untuk menentukan besarnya sampel pelanggan digunakan rumus Machin dan Campbell karena jumlah populasinya tidak diketahui. Kuesioner dibagikan kepada 120 responden dengan purposive sampling. Purposive sampling adalah nonprobability sampling yang menggunakan kriteria tertentu. Kriteria sampel dalam penelitian ini adalah:

1. Nasabah Bank Muamalat yang melakukan transaksi lebih dari atau sama dua kali.

2. Nasabah Bank Muamalat telah menjadi nasabah minimal satu tahun.

Pada penelitian ini terdapat tiga hipotesis. Menurut Malhotra dan Peterson (2006) menjelaskan bahwa hipotesis adalah pernyataan atau proposisi yang tidak terbukti tentang suatu faktor atau fenomena yang menarik minat seorang peneliti. Berdasarkan gambaran empiris dan teoritis model hipotetik dalam penelitian ini sebagai berikut:

H1: Ada pengaruh Islamic Matketing terhadap Kepuasan Pelanggan 
H2: Ada pengaruh Islamic Marketing terhadap Loyalitas Pelanggan

H3: Ada pengaruh Loyalitas Pelanggan terhadap Kepuasan Pelanggan

\section{HASIL DAN PEMBAHASAN}

\section{Konsep Islamic Marketing, Customer satisfaction dan Customer loyalty}

\section{Islamic Marketing}

Menurut Kertajaya dan Sula (2006) Islamic Marketing merupakan disiplin bisnis strategis yang mengarah pada proses penciptaan, penawaran, dan perubahan nilai dari pemrakarsa menjadi pemangku kepentingan dalam keseluruhan proses sesuai dengan akad dan prinsip-prinsip Muamalah. Menurut Hussnain (2011) Islamic marketing merupakan proses identifikasi dan implementasi strategi maksimisasi nilai untuk kesejahteraan stakeholder pada khususnya dan masyarakat pada umumnya diatur dengan pedoman yang diberikan dalam Alquran dan Sunnah. Selain itu Alom dan Haque (2011) mendefinisikan Islamic Marketing adalah proses dan strategi (Hikmah) pemenuhan kebutuhan melalui produk dan jasa Halal (Tayyibat) dengan kesepakatan dan kesejahteraan bersama (Falah) dari kedua belah pihak pembeli dan penjual untuk tujuan pencapaian tujuan. kesejahteraan material dan spiritual di dunia di sini dan di akhirat.

Ada empat karakteristik yang dapat dijadikan pedoman bagi pemasar untuk memasarkan barang dan jasanya. Ciri-cirinya sebagai berikut:

a. Rabbaniyah (Teistik)

Rabbaniyyah adalah karakteristik yang tidak dimiliki oleh pemasaran konvensional. Pada prinsipnya pemasar Rabaniyyah menekankan pada prinsip diniyyah atau religiusitas. Nilai tersebut bersumber dari kesadaran beragama yang dianggap esensial untuk mewarnai kegiatan pemasaran yang tidak merugikan pihak lain.

b. Akhlaqiyah (Etika)

Seorang Islamic Marketer dalam melakukan aktivitas pemasaran harus mengedepankan nilai-nilai Akhlak (moral dan etika). Berbagai aktivitas bisnis yang dilakukan oleh perusahaan tidak lagi menjadikan nilai-nilai moral sebagai pedoman. Hal ini menyebabkan segala cara dalam bisnis dianggap dilakukan. Akhaqiyyah berasal dari konsep Rabaniyyah. Konsep ini berlaku untuk semua manusia tanpa memandang agamanya.

c. Waqiyyah (Realistis)

Islamic Marketingi bukanlah pemasaran eksklusif, fanatik terhadap kelompok tertentu, anti pembaruan atau modernitas dan tidak fleksibel atas perubahan lingkungan. Islamic Marketingi adalah konsep pemasaran yang fleksibel, 


\section{Journal Publicuho}

ISSN2621-1351 (online), ISSN 2685-0729 (print)

sebagai keluasan dan fleksibilitas yang mendasari Syariah Islamiyah. Dengan demikian, Islamic Marketing harus realistis untuk diterapkan.

d. Al-Insaaniyyah (Humanistik)

Keistimewaan Islamic Marketing adalah sifat humanistik. Al-Insyaaniyyah adalah syariah yang diciptakan untuk meningkatkan derajat kemanusiaan; sifat melestarikan dan memelihara kemanusiaan. Marketer Islam dengan nilai Al-Insaaniyyah akan terkontrol dan tawazun (Seimbang).

\section{Customer Satisfaction}

Kepuasan adalah konsep pemasaran yang penting. Menurut Kotler dan Keller (2009) kepuasan adalah perasaan senang atau kecewa akibat membandingkan kinerja suatu produk dengan harapan yang diinginkan. Jika kinerja suatu produk gagal memenuhi ekspektasi pelanggan akan kecewa, jika kinerja produk melebihi ekspektasi maka akan timbul kepuasan.

Berdasarkan penelitian yang dilakukan oleh Richard (2007) menyatakan bahwa terdapat tiga faktor yang mempengaruhi kepuasan nasabah di sektor perbankan, yaitu:

a. Hubungan dan layanan pelanggan

b. Staf kompeten dan tanggap

C. Perbankan yang nyaman.

\section{Customer Loyalty}

Menurut Kotler dan Keller (2009) loyalitas pelanggan adalah komitmen yang kuat untuk membeli lagi atau berlangganan kembali pada produk atau jasa tertentu di masa depan meskipun situasi dan upaya pemasaran mengarah pada perilaku transisi. Loyalitas merupakan perilaku pelanggan dalam menentukan pilihan untuk tetap menggunakan produk atau jasa dari suatu perusahaan. Perilaku pilihan juga membuat komitmen dan melakukan pembelian berulang perusahaan. Menurut Griffin (2005: 31) loyalitas dapat didefinisikan melalui perilaku pembelian.

\section{Analisis Deskriptif}

Nasabah Bank Muamalat berasal dari berbagai latar belakang pendidikan dan mayoritas memiliki tingkat pendidikan tinggi. Penelitian ini didominasi oleh responden berusia 33 sampai dengan 37 tahun dengan jumlah 27 orang. Tabungan Bank Muamalat merupakan produk yang paling banyak digunakan oleh pelanggan. Nasabah Bank Muamalat menggunakan produk dengan jangka waktu yang berbeda dan didominasi lebih dari 2 sampai dengan 4 tahun. Untuk jumlah transaksi lebih dari 2 sampai dengan 5 kali dalam sebulan memiliki frekuensi tertinggi yang dilakukan oleh responden. Karakteristik responden berdasarkan faktor-faktor yang mempengaruhi menjadi nasabah menunjukkan komitmen beragama merupakan faktor dominan yang mempengaruhi menjadi nasabah Bank Muamalat. 
ISSN2621-1351 (online), ISSN 2685-0729 (print

Volume 4 Number 2 (May-July-2021) pp.239-247

DOI: $10.35817 /$ jpu.v4i2.17704

\section{Analisis Jalur}

Hasil analisis jalur yang telah dihitung peneliti antar variabel dapat dilihat pada Tabel 1.

Tabel 1. Hasil Analisis Jalur

\begin{tabular}{llllll}
\hline Exogenous Variable & Endogenous Variable & Beta & † test & $\begin{array}{l}\text { P- } \\
\text { Value }\end{array}$ & Explanation \\
\hline Islamic Marketing & Customer Satisfaction & 0.414 & 4.212 & 0.000 & Significant \\
\hline Islamic Marketing & Customer Loyalty & 0.317 & 3.198 & 0.002 & Significant \\
\hline Customer Satisfaction & Customer Loyalty & 0.174 & 2.137 & 0.034 & Significant \\
\hline
\end{tabular}

Sumber: Hasil Olahan Penulis

\section{Pembahasan}

1. Pengaruh Islamic Marketing terhadap Kepuasan Pelanggan.

Variabel Islamic marketing berpengaruh signifikan terhadap kepuasan pelanggan. Pengaruh tersebut ditunjukkan dengan nilai koefisien jalur $(\beta)$ yang diperhitungkan 0,414 dengan nilai-p bilangan $0,000(p<0,05)$. Pengaruh yang signifikan berarti semakin meningkat tingkat Islamic Marketing Bank Muamalat maka kepuasan nasabah akan meningkat. Dalam penelitian ini nasabah Bank Muamalat merasa puas karena Islamic Marketingi mengedepankan nilai-nilai Islam, misalnya rabbaniyah (semua perilaku berdasarkan nilai agama), akhalqiyah (berdasarkan nilai-nilai moral), al waqiyah (realistis) dan insaniyyah (rasa hormat manusia).

Hasil penelitian ini sejalan dengan proses pemasaran spiritual. Menurut Hasan (2008) proses pemasaran spiritual adalah proses yang menjelaskan tentang cara pemasaran spiritual yang mampu memberikan kepuasan kepada pelanggan dan loyalitas dari pelanggan kepada perusahaan. Pemasaran berdasarkan nilai-nilai spiritual dalam konteks Islamic Marketingi mampu memenangkan mind share, pangsa pasar, dan pangsa hati pelanggan. Pangsa pikiran, pangsa pasar, dan hati saham yang membentuk jiwa pemasaran akhirnya memberikan kepuasan kepada pelanggan. Hasil penelitian ini mendukung penelitian Habib (2014) yang menjelaskan bahwa Islamic Marketing berpengaruh signifikan terhadap kepuasan pelanggan. Menurut Habib perusahaan harus memberikan pelayanan yang terbaik bagi pelanggannya dan meningkatkan layanan Islamic Marketing secara maksimal. Hasil penelitian ini juga diperkuat oleh Agustina (2011) yang menjelaskan bahwa Islamic Marketing berpengaruh signifikan terhadap kepuasan pelanggan. Menurut Shahi et al. (2014) Etika Islam yang merupakan bagian dari Islamic Marketing juga berpengaruh terhadap kepuasan pelanggan, oleh karena itu organisasi bisnis dalam syariah harus menerapkan etika yang sesuai dengan prinsip syariah. Bank syariah perlu memperhitungkan indeks kepuasan pelanggan dan faktor-faktor yang mempengaruhinya citra perusahaan Bank Muamalat meningkat maka kepuasan nasabah akan meningkat. 


\section{Journal Publicuho}

ISSN2621-1351 (online), ISSN 2685-0729 (print)

Volume 4 Number 2 (May-July), (2021)pp. 239-247

Accredited SINTA SK.NOMOR 28/E/KPT/2019

Open Access at:http://ojs.uho.ac.id/index.php/PUBLICUHO/index

DOI: 10.35817/jpu.v4i2.17704

2. Pengaruh Islamic Marketing terhadap Loyalitas Pelanggan

Hasil perhitungan analisis jalur menunjukkan bahwa Islamic Marketing yang terdiri dari indikator rabbaniyah, akhalqiyah al waqiyah dan al insaniyyah berpengaruh signifikan terhadap loyalitas pelanggan berpengaruh signifikan ditunjukkan dengan nilai koefisien jalur $(\beta)$ sebesar 0,317 dan $p$-value dengan angka $0,002(p<0,05)$. Pengaruh yang signifikan artinya jika tingkat Islamic Marketing Bank Muamalat meningkat maka loyalitas nasabah akan meningkat.

Hasil penelitian ini sejalan dengan penelitian yang dilakukan oleh Rizqia (2013) yang menjelaskan bahwa pemasaran spiritual atau Islamic Marketingi secara simultan memiliki pengaruh yang signifikan terhadap loyalitas pelanggan. Selain itu hasil penelitian ini sejalan dengan penelitian yang dilakukan oleh Shahi et al. (2011) yang menyatakan etika bisnis Islam yang merupakan bagian dari Islamic Marketing berpengaruh signifikan terhadap loyalitas pelanggan. Menurut Hasan (2010) loyalitas pelanggan merupakan kunci sukses tidak hanya dalam jangka pendek tetapi juga jangka panjang.

Loyalitas memiliki nilai strategis bagi perusahaan, oleh karena itu bank untuk meningkatkan loyalitas nasabahnya perlu meningkatkan Islamic Marketing. Bank Muamalat perlu meningkatkan nilai-nilai Islam yang ada dalam Islamic Marketing yaitu rabbaniyah, akhalqiyah, al waqiyah dan insaniyyah. Nasabah Bank Muamalat yang loyal diharapkan memiliki karakteristik yang sesuai dengan teori yang dikemukakan oleh Griffin (2005). Mereka melakukan transaksi secara berulang-ulang, menggunakan produk bank Muamalat yang lain, dan mereferensikan produk Bank Muamalat kepada orang lain, serta menunjukkan penolakan terhadap tarikan pesaing. Berdasarkan hasil penelitian dapat disimpulkan bahwa Islamic Marketing merupakan strategi yang dapat digunakan oleh bank untuk meningkatkan loyalitas nasabahnya.

3. Pengaruh Kepuasan Pelanggan terhadap Loyalitas Pelanggan.

Hasil perhitungan analisis jalur menunjukkan bahwa kepuasan pelanggan berpengaruh signifikan terhadap loyalitas pelanggan. Pengaruh yang signifikan ditunjukkan dengan nilai koefisien jalur $(\beta)$ sebesar 0,174 dan nilai $p$ dengan angka $0,034(p<0,05)$. Pengaruh yang signifikan artinya jika tingkat kepuasan nasabah Bank Muamalat meningkat maka loyalitas nasabah akan meningkat.

Temuan penelitian ini sesuai dengan teori yang dijelaskan oleh Tjiptono et al. (2008) yang menyatakan kepuasan pelanggan berpengaruh positif terhadap loyalitas dan potensi pendapatan dimasa yang akan datang terutama melalui repeat sales dan cross selling serta mampu menekan biaya transaksi. Selain itu, penelitian ini juga sesuai dengan model konseptual loyalitas pelanggan yang menjelaskan kepuasan pelanggan berpengaruh terhadap loyalitas pelanggan (Hasan, 2010). Jika produk atau jasa yang diharapkan 
pelanggan sesuai dengan kinerjanya maka pelanggan akan puas. Kepuasan akan mempengaruhi customer untuk mengulang pembelian, dan repeat buying bagian dari customer loyalty.

\section{KESIMPULAN}

Berdasarkan penelitian yang telah dilakukan peneliti dapat disimpulkan sebagai berikut:

1. Islamic Marketing berpengaruh signifikan terhadap kepuasan pelanggan. Artinya Islamic Marketing yang dilakukan oleh Bank Muamalat mampu mempengaruhi kepuasan nasabah.

2. Islamic Marketing berpengaruh signifikan terhadap loyalitas pelanggan. Artinya Islamic Marketing yang dilakukan oleh Bank Muamalat mampu mempengaruhi loyalitas nasabah.

4. Kepuasan pelanggan berpengaruh signifikan terhadap loyalitas pelanggan. Artinya apabila nasabah Bank Mualamat puas dengan produk atau jasa yang ditawarkan, maka hal tersebut dapat berdampak pada loyalitas nasabah.

\section{Rekomendasi}

Berdasarkan kesimpulan tersebut, hal-hal yang perlu diperhatikan oleh Bank Muamalat dan penelitian selanjutnya adalah sebagai berikut:

1. Manajemen Bank Muamalat Cabang Malang harus dapat menjaga dan meningkatkan indikator Islamic Marketing, karena Islamic Marketing memiliki pengaruh yang signifikan. berpengaruh pada kepuasan pelanggan dan loyalitas pelanggan. Strategi yang dapat digunakan Bank Muamalat untuk meningkatkan Islamic Marketing sebagai berikut; pertama, memastikan semua produk yang ada di Bank Muamalat sesuai dengan kaidah Islam, termasuk semua proses bisnis dari modal yang diperoleh dan aktivitas lainnya. Kedua, meningkatkan kualitas pembinaan kepada pegawai Bank Muamalat mengenai tata tertib dalam bisnis syariah dan produk yang ditawarkan, sehingga pegawai memiliki pengetahuan yang lebih baik.

2. Untuk penelitian selanjutnya diharapkan dapat mengkaji variabel-variabel lain di luar penelitian yang telah diteliti ini, untuk mendapatkan gambaran yang lengkap tentang Islamic Marketing. 


\section{Journal Publicuho}

ISSN2621-1351 (online), ISSN 2685-0729 (print)

\section{DAFTAR PUSTAKA}

Agustina, Anisa (2011) Pengaruh Karakteristik Syari'ah Marketing terhadap Kepuasan Nasabah pada BPRS Artha Abadi Pati. Retrieved November 25, 2014 from http://library.walisongo.ac.id/digilib/file s/disk1/102/jtptiain-gdl-anisaagust- 5051-1fileskr-a.pdf

Alom, Md Mahabub, Md. Shariful Haque (2011) Marketing: an Islamic Perspective. World Journal of Social Sciences, 1:3 pp. 71-81.

Imacaward (2016) Survey Results.Retrieved November 25, 2016 from http://imacaward.com/2016-survey- results/

Bank Muamalat (2018) Annual Report: Managing The Importance of Corporate the Challenge of Growth. Retreived November 25, 2018 from http://www.idx.co.id/Portals/O/StaticDat a/NewsAndAnnouncement/ANNOUNC EMENTSTOCK/From_EREP/201406/3186af19a4_453838ceda.pdf

BPS (2010) Kewarganegaraan, Suku Bangsa, Agama, dan Bahasa Sehari-hari Penduduk Indonesia Hasil Sensus Penduduk 2010. Jakarta: Badan Pusat Statistik.

Cengiz, Emrah (2010) Measuring Cusomer Satisfaction Must or Not?. Journal of Naval and Science Enginering, 6:2 pp. 76- 88

Griffin, Jill (2005) Menumbuhkan dan Mempertahankan Kesetiaan Pelanggan. Jakarta: Erlangga.

Habibi, Ahmad (2014) Pengaruh Karakteristik Syari'ah Marketing terhadap Kepuasan Nasabah pada BPD Syariah Cabang Yogyakarta. Retreived November 25, 2014 from http://digilib.uin-suka.ac.id/13311/2/BAB\%20l,\%20V,\% ODAFTAR\%2OPUSTAKA.pdf

Hassan, Abul, Abdelkader Cachi, and Salma Abdul Latif (2008) Islamic Marketing Ethics and Its Impact on Customer Satisfactioni in Islamic Banking Industry. JKAU Econ, 21:1, pp. 27-46

Hussnain, Syed Ali. (2011) What is Islamic Marketing. Global Journal of Management and Business Research, 11:11, pp. 100-103

Kertajaya, Hermawan and Syakir Sula. (2006) Syariah Marketing. Jakarta: PT Mizan Media Utama

Kotler, Philip and Kevin Lane Keller (2009) Manajemen pemasaran. 13th ed. Jakarta: Erlangga

Malhotra, Naresh K, Mark Peterson (2006) Basic Marketing Research: Decision-Making Approach. Second Edition. New Jersey: Prentice Hall

Marketing.co.id (2014) Pemenang Excellent Service Experience Award (ESEA) 2014.

Richard, Oduro (2007) Factors That Determine Customer Satisfaction Level in Banking Institutions: Evidence from Ghanaian Banking Industry. Asian Journal of Business and Management Sciences, 2:7, pp. $1-13$

Shahi, Kalhor, and Javanmard (2014) Impact of Islamic Ethics Iranian on Customer Satisfaction Index Model. Indian Journal Science Research, 4:6, pp. 373-380.

Tjiptono, Fandy dan Anastasia Diana (2003) Total Quality Manajemen. Edisi Revisi. Yogyakarta : Penerbit Andy 